\title{
Profound Presentation of Retinopathy in a Patient with Sickle Cell Trait and Diabetes Mellitus
}

\author{
Gautam Vangipuarm ${ }^{1}$, MD; Steven S. Saraf ${ }^{1}$, MD; Qinqin Zhang ${ }^{2}$, PhD; Ruikang Wang1,2, PhD; Kasra A Rezaei ${ }^{1}$, \\ MD
}

${ }^{1}$ Department of Ophthalmology, University of Washington, Seattle, WA, USA

${ }^{2}$ Department of Bioengineering, University of Washington, Seattle, WA, USA

ORCID:

Kasra A Rezaei: https://orcid.org/0000-0003-4287-3187

J Ophthalmic Vis Res 2020; 15 (1): 116-117

\section{Correspondence to:}

Kasra A Rezaei, MD. University of Washington, Department of Ophthalmology, Seattle, WA, 908 Jefferson St, Seattle, WA 98104.

E-mail: krezaei@uw.edu

Received: 01-01-2019 Accepted: 01-05-2019

\section{Access this article online}

Website:

https://knepublishing.com/index.php/JOVR

DOI:

10.18502/jovr.v15i1.5962

\section{PRESENTATION}

A 43-year-old functionally monocular African American woman with longstanding type 2 diabetes mellitus presented for care of her better-seeing left eye. Originally suspected of having proliferative diabetic retinopathy (PDR) as the cause of her bilateral visual impairment, fluorescein angiography and optical coherence tomography angiography revealed a marked peripheral nonperfusion which was out of proportion for a typical diabetic retinopathy (Figure 1). A comprehensive uveitic and vasculopathic workup was therefore initiated. The workup was largely negative except for hemoglobin electrophoresis, which was consistent with the sickle cell trait (or hemoglobinopathy) (Table 1). The patient was counseled on her diagnosis and continues to be treated with laser photocoagulation for her peripheral neovascularization.

Figure 1. Color fundus photo, left eye (A) early (B) and late (C) fluorescein angiography of the left eye showing marked peripheral ischemia and posterior pole neovascularization. OCT angiography (D) showing severely decreased vascular density.

This is an open access journal, and articles are distributed under the terms of the Creative Commons Attribution-NonCommercial-ShareAlike 4.0 License, which allows others to remix, tweak, and build upon the work non-commercially, as long as appropriate credit is given and the new creations are licensed under the identical terms.

This report strengthens the hypothesis that diabetic retinopathy and coexisting vasculopathic 
Table 1. Laboratory assessment of other etiologies for extensive peripheral non-perfusion including pro-thrombotic and vasculitic causes

Test ordered

Angiotensin converting enzyme (U/L)

Anti-nuclear antibody

Cryoglobulin

Erythrocyte sedimentation rate $(\mathrm{mm} / \mathrm{H})$

HIV $A g$ and $A b$

Anti-myeloperoxidase

Anti PR3

Rheumatoid factor

Serologic syphilis panel

Anti-thrombin activity

C-reactive protein (mg/L)

Activated protein S (\%)

Activated protein C (\%)

Factor $\mathrm{V}$ Leiden

Homocysteine

Prothrombin time (s)

INR (s)

$\mathrm{CBC}$

CMP

Herpes type $1 \& 2$ serology

CMV (serum antibody)

Hemoglobin electrophoresis

Quantiferon-TB Gold
Result (normal range)

26U/L (8-53 U/L)

Negative

Negative

60 mm/H high $(0-20$ mm/H)

Nonreactive

Negative

Negative

$<10$

Negative

123\% (normal)

$24.9 \mathrm{mg} / \mathrm{L}$ high $(0-10 \mathrm{mg} / \mathrm{L})$

$113 \%$ (65-150\%)

121\% (55-150\%)

Negative

Negative

$14.1 \mathrm{~s}(10.7-15.6 \mathrm{~s})$

$1.1 \mathrm{~s}(0.8-1.3 \mathrm{~s})$

Normal

Glucose 353 mg/dL (62-125 mg/dL)

Positive for HSV-1 and HSV-2

Positive

Consistent with $\mathrm{HbS}$ trait

Negative

CBC, complete blood count; CMP, comprehensive metabolic panel; CMV, antibodies to cytomegalovirus; HIV, human immunodeficiency virus; INR, international normalized ratio; $\mathrm{mg} / \mathrm{dL}$, milligrams per deciliter; $\mathrm{mm} / \mathrm{H}$, millimeter per hour $\mathrm{U} / \mathrm{L}$, Units Per Liter

diseases, even sickle cell trait, may have a synergistic effect on the overall disease burden. A broad differential must be maintained in patients with presumed diabetic retinopathy, especially those with uncharacteristic imaging findings. ${ }^{[1-5]}$

\section{Financial Support and Sponsorship}

This study was supported by the Department of Ophthalmology, University of Washington.

\section{Conflicts of Interest}

There are no conflicts of interest.

\section{REFERENCES}

1. Tsaras G, Owusu-Anash A, Boateng FO, AmoatengAdjepong Y. Complications associated with SCT: A brief narrative review. Am J Med 2009;122:507-512.

2. Downes S, Hambleton I, Chuang EL, Lois N, Serjeant GR, Bird AC, et al. Incidence and natural history of proliferative sickle cell retinopathy. Ophthalmology 2005;112:18691875

3. Jampol L, Goldbaum M. Peripheral proliferative retinopathies. Surv Ophthalmol 1980;25:1-14

4. Jackson $\mathrm{H}$, Bentley $\mathrm{CR}$, Hingorani $\mathrm{M}$, Atkinson, $\mathrm{P}$ Aclimandos WA, Thompson GM. Sickle retinopathy in patients with sickle trait. Eye 1995;9:589-593.

5. Nagpal KC, Asdourian GK, Patrianakos D, Goldberg MF, Rabb MF, Goldbaum M. Proliferative retinopathy in SCT. Report of seven cases. Arch Intern Med 1977;137:325-328. 